\title{
DETERMINANTS OF CUSTOMER LOYALTY: A FIELD RESEARCH IN AVIATION INDUSTRY
}

Nuriye Güreş

Iskenderun Technical University, Hatay, Turkey

Hilal İnan

Çukurova University, Adana, Turkey

Seda Arslan

Iskenderun Technical University, Hatay, Turkey

\section{ABSTRACT}

The encouragements of Turkish government for aviation industry in 2003 have paved the way for private airlines to enter the market. Through the increasing number of airlines and the rivalry between them, especially low-cost carriers have started to give transportation service with cheaper ticket prices. According to The International Air Transportation Association (IATA) estimates, the number of passengers travelling with airlines around the world will reach to 3.8 billion passengers in 2020 and low-cost carriers' flight networks and numbers especially in developing countries as Turkey will continue to gain momentum. When considering the increased passenger traffic in Turkish travel industry, providing the passenger loyalty for Turkish low-cost carriers has also become obligatory for these companies' survival in the longrun. In this study, determinants of passengers' loyalty as perceived value and trust have been searched. For this purpose, 350 questionnaires were applied to the passengers travelling with low-cost carriers at Hatay and Adana Airports in Turkey, 311 of which were analyzed after eliminating invalid ones. Structural equation modelling was applied for data analysis. According to the analysis results, perceived value and trust were identified as the important determinants of passenger loyalty.

\section{KEYWORDS}

Airline Marketing, Low-Cost Carriers, Perceived Value, Trust, Passenger Loyalty, Turkish Aviation Industry.

Assc. Prof. Nuriye Gures has been working in Iskenderun Technical University, School of Civil Aviation since 2007 and she is the Chair of Aviation Department. She has been studying Marketing, Customer Relationship Marketing and Airline Marketing. Email: nuriye.gures@iste.edu.tr , Tel.: +90 3266135600 / 5202

Prof. Hilal Inan has been working in Cukurova University, Faculty of Economics and Administrative Sciences, Department of Business Administration. She has been studying Marketing and Services Marketing. Email: ihilal@cu.edu.tr , Tel.: +90 3223386084

Res. Asst. Seda Arslan has been studying in Iskenderun Technical University School of Civil Aviation, Department of Aviation Management since 2009. She has been attending to her doctorate degree program and studying Airline Marketing, Social Media and Technology in Services. Email: seda.arslan@iste.edu.tr, Tel: +90 3266135600 / 5206 


\section{INTRODUCTION}

In recent years, there has been important progress in Turkish Aviation Industry. The Turkish Government has been giving more support to the airlines performing in the sector since 2003. By this way, the liberalization in this market has increased and new airlines have entered the sector. Thus, both domestic and international airlines have put in an appearance in Turkish Airline Market and the competition among them has also gone up. Because of the increasing intense competition in the industry, some airlines have preferred to put a new business model to use named Low-cost carriers (LCC).

LCC includes airlines that use aggressive, competitive mind-sets to gain competitive advantages and better returns than their counterparts "traditional airlines" (Akamavi et al., 2015; Graf, 2005; Kangis \& O'Reilly, 2003; Kumar, 2006; McLay \& Reynolds-Feighan, 2006; Porter, 1996). Also, Low cost carriers (LCCs) can be defined as the airlines which offer lower fares to attract passengers by reducing their service costs by means such as reducing free inflight services, standardizing airplane fleet and cabins, increasing luggage restrictions, benefiting from direct distribution channels (internet, smart phones, social media, etc...) and using secondary airports (Chang \& Hung, 2013).

In international aviation industry, there are many airlines using this competitive strategy such as Southwest Airlines in the USA, Rynair, Easyjet, Germanwings in Europe and Pegasus in Turkey. Along with rising number of LCC, traditional airlines have been adding new and different service qualifications (flying chef, in-flight entertainment service cost free, wider spaces between the seats, etc...) to overcome the competition with LCC. Thus, providing passenger loyalty has become more important for LCC.

At the same time, the LCC has become an interesting research area and it has attracted the attention of numerous scholars worldwide (Barrett, 2004; Zou et al. 2014; Akamavi et al, 2015; Chang \& Hung, 2013; Chiou \& Chen, 2010; Forgas et al, 2010; Han et al, 2014; Han, 2013; Mikulić \& Prebežac, 2011; Yang et al., 2012; Diggines, 2010; Pan \& Truong, 2018; Taumoepeau et al., 2017; Zuidberg \& de Wit, 2016; Lu, 2017; Bachwich \& Wittman, 2017; Rajaguru, 2016; Koklic et al., 2017).

Despite the growing importance of the subject in international literature, the studies made in this field are relatively limited in Turkey. There are a few studies related to the passenger loyalty in aviation (Mutlu \& Polat Seslikoyuncu, 2015; Atalık, 2005; Atalık, 2006; Çalışır et al., 2015), but there isn't any study about Turkish passengers' loyalty with LCC. For this reason in this study, Turkish passengers' loyalty towards LCC and the factors as perceived value and trust that may effect the loyalty were searched. 


\section{LITERATURE REVIEW}

\subsection{Customer Loyalty}

Customer loyalty is defined as "a deeply held commitment to rebuy or repatronize a preferred product / service consistently in the future, thereby causing repetitive same-brand or same brand-set purchasing, despite situational influences and marketing efforts having the potential to cause switching behavior." (Oliver, 1999).

Customer loyalty may provide positive word-of-mouth and word-of-mouse (Severt et al, 2007), reduces marketing costs abd turnover expenses, increases cross-selling (Caruana, 2004; Griffin, 1995; Reichheld \& Sasser, 1990; Yang and Liu, 2003). Besides the costs of winning a new customer are six times greater than the costs of maintaining an existing customer (Akamavi et al, 2015).

Customer loyalty is important to airline companies, too. Because passenger loyalty is one of the key indicators that influence competitive advantage in the global airline market (Cooil et al., 2007; Mägi, 2003; Wirtz et al, 2007; Akamavi e .al, 2015). If airlines want a sustainable market share, they should provide passenger loyalty (Chang \& Hung, 2013; Kumar \& Shah, 2004). According to Binggeli, Gupta, and de Pommes (2002) passenger loyalty may increase airlines' revenue by as much as $2.4 \%$ per year.

\subsection{Perceived Value}

Perceived value is a very important concept in marketing because according to researches, one of the important determinants of customer satisfaction is perceived value (Cronin et al., 2000; Chen, 2008; Oh, 1999). Also, improved customer satisfaction and high product value offers are the important factors of developing loyalty (Yang and Peterson, 2004). According to Zeithaml (1988), perceived value is "consumers' overall assessments of the utility of a product based on perceptions of what is received (volume, high quality or convenience) and what is given (money, time or effort)". Based on the equity theory, perceived value concept can be explained through comparing benefits and sacrifices associated with the offering. (Yang and Peterson, 2004). Perceived benefits can be explained as a combination of different product attributes available in relation to a particular buy and use situation (Snoj et al.,2004). The overall cost or sacrifice made by the customer includes both monetary (such as price of the product) and nonmonetary costs (such as time, effort and search) (Sánchez-Fernández and Iniesta-Bonillo, 2007; Lovelock and Wirtz, 2011). 


\subsection{Trust}

Trust is a key factor in successful marketing (Urban et al., 2000), especially in building and continuing long-term relationships (Akbar and Parvez, 2009). According to Gundlach and Murphy (1993), trust is the most universally accepted factor in any human interaction or exchange. Bhattacharya, Devinney and Pillutla (1998) define trust as "an expectancy of positive outcomes that one can receive based on the expected action of another party in an interaction characterized by uncertainty".

Many studies mentioned the relationship between trust and loyalty (Sirdeshmukh et al., 2002; Kassim and Abdullah 2010; Ndubisi, 2007). According to Reichheld and Schefter (2000), gaining the trust of the right customers generate loyalty. Also according to Ndubisi (2007), trust is an important factor of firm-customer relationships and so in generating the loyalty. In their research Akbar and Parvez (2009) found out that both "trust and customer satisfaction are significantly and positively related to customer loyalty" and they mentioned trust as an important antecedent of customer loyalty.

\section{METHODOLOGY}

Considering the literature and the survey purpose, hypotheses were defined as follows:

H1: The value perceived by a user in respect of an airline directly and positively influences the user's trust in the airline

H2: The value perceived by a user in respect of an airline directly and positively influences the user's loyalty to the airline

H3: A user's trust in an airline directly and positively influences the user's loyalty to the airline The proposed research model can be seen in Figure 1.

\subsection{Measures of the Constructs}

The survey questionnaire consisted of four sections. The first three sections were designed to obtain each respondent's perceived value (9-item), trust (4-item) and loyalty (4-item) towards LCC. All these scales were measured using the scale developed by Forgas et al (2010), but perceived value was adapted to our study. Respondents were asked to indicate their agreement level of each item of the first three sections on the 5-point Likert scale organized by "strongly disagree $(=1)$ " to "strongly agree $(=5)$ ". Survey questionnaires were translated into Turkish and then implemented to Turkish passengers preferred LCC. The last section reported the respondents' demographic and flight information as; gender, age, education 
level, average monthly income, airline decision, flight type, flight purpose, flight frequency and the reason for selecting this airline via a categorical scale.

Figure 1: Research Model

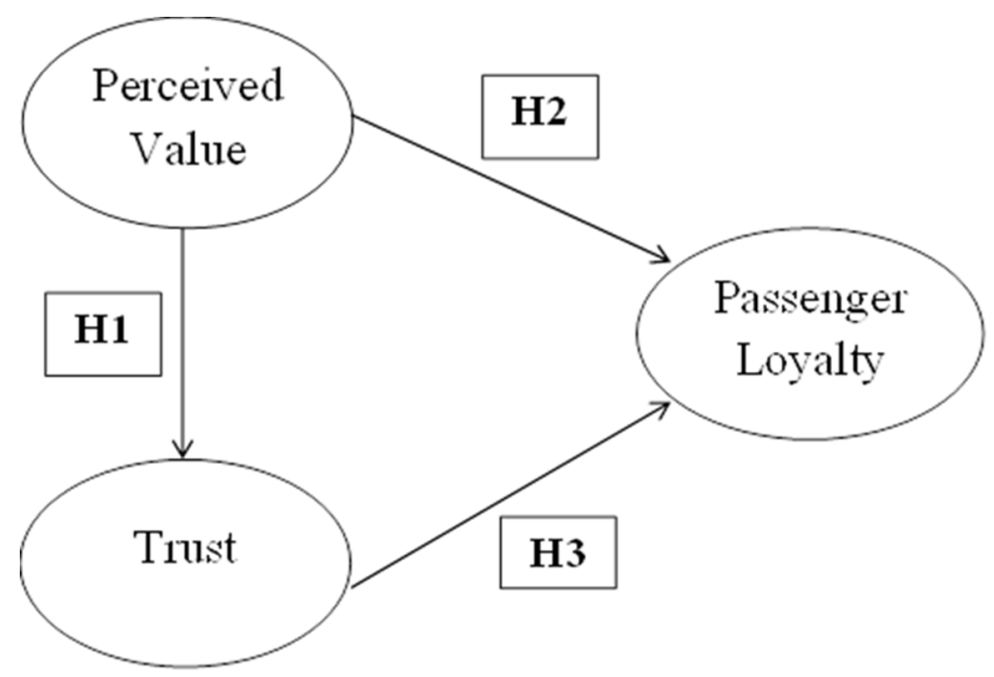

\subsection{Data Collection and Sample Design}

A self-administered questionnaire survey was conducted at Hatay and Adana airports in Turkey. In this study, convenience sampling was used as the sampling method. Respondents were first asked whether they experienced LCC before. If they replied positively, then they were invited to participate in the survey. For each question, respondents were asked to give an answer which best describes their degree of agreement. The data was collected from 311 Turkish passengers experienced LCC before.

The demographic characteristics of the respondents were as follows; 57.2 percent of them were male and 42.8 percent were female. The great majority of the respondents were aged between 20 and 29 years old (69.1 percent), had a university degree or higher educational level (93.9 percent) and domestic passengers (88 percent) as flight type. Respondents' average monthly income was mostly ranged between 1000-3000 TL (61.1 percent). Most of the respondents had a flight for vacation purposes ( 40.5 percent) and visiting friends/relatives purposes (23.5 percent), they had made the airline decision themselves ( 72.7 percent) and their flight frequency was once a quarter were $41.2 \%$. Price was found as the most important reason for selecting airlines (62.1\%) compared to other factors as experience $(20.3 \%)$, advertising (4.8\%), recommendation (9.3\%) and others (3.5\%).

\subsection{Data Analysis}

In order to analyze the data, confirmatory factor analysis (CFA) and structural equation modeling (SEM) analysis were applied by using LISREL. Thus, it was aimed to check construct validity, the goodness-of-fit indices for the measurement and structural models and examine the relationship among constructs. In addition, frequency analysis was implemented to 
analyze the demographic variables by using SPSS. The Cronbach alpha reliability scores of the scales were found as $a=0,85$ for perceived value, $a=0,78$ for trust and $a=0,89$ for loyalty.

\section{RESULTS}

\subsection{Measurement Model}

A confirmatory factor analysis using LISREL 8.5.1 was conducted to test the measurement model. The goodness-of-fit indices were used to assess the overall model fit. According to the results of the study, the fit indices for the measurement model were acceptable level as; the ratio of the Chi-square value to degrees of freedom $(x 2 /$ d.f. $=2.93)$ is less than 3 and other indices such as normalized fit index (NFI=0.91), goodness of fit index (GFI=0.92) and comparative fit index $(\mathrm{CFI}=0.92)$ are greater than the recommended value of 0.9 . The root mean - square error of approximation (RMSEA) is 0.081 , which is less than 0.10 . (Hair et al., 2006). The goodness-of-fit indices from confirmatory factor analysis demonstrated that the measurement model had a good fit with the data collected.

As seen in Table 1, the average variance extracted (AVE) was used to assess convergent validity. AVE of each measure ranges from 0.68 to 0.83 , which was more than 50 percent of the variance as suggested by Bagozzi \& Yi (1988) and indicated that the convergent validity was appropriate. Discriminant validity was assessed by comparing the AVE with the squared correlation between constructs (Fornell \& Larcker, 1981). The squared correlations between pairs of constructs were less than the AVE, confirming discriminant validity. Moreover, a descriptive analysis was run on each construct to measure their means: perceived value (3.61), trust (3.79), and loyalty (3.89).

Perceived value, the independent latent variable, has consisted of nine items and all of the items have got positive coefficients. The highests of these observed variables is PV4 (0.76) and PV9 (0.72). This means that if social value (PV4) of the airline company and the professionalism of the personnel (PV9) increase, perceived value of the passengers may increase positively too. Similarly, trust, latent variable, has comprised of four items and all of them have got positive coefficients. T2 (0.76) and T3 (0.76) observed variables have got the highest values. From this viewpoint, it can be said that if the airline companies fulfil their responsibilities truly and meet the needs of passengers effectively, trust level of passengers can be concluded positively towards the airline company. 
Table 1: Confirmatory factor analysis results

\begin{tabular}{|c|c|c|c|c|}
\hline \multicolumn{2}{|c|}{ Indicator } & \multirow{2}{*}{$\begin{array}{c}\begin{array}{c}\text { Standardized Factor } \\
\text { Loading }\end{array} \\
0.69\end{array}$} & \multirow{2}{*}{$\begin{array}{c}\mathrm{t} \\
\text { value } \\
13.21\end{array}$} & \multirow[t]{2}{*}{$\begin{array}{c}\text { Average variance } \\
\text { extracted } \\
\text { (AVE) }\end{array}$} \\
\hline \multirow{9}{*}{$\begin{array}{l}\text { Perceived } \\
\text { Value }\end{array}$} & PV1 & & & \\
\hline & PV2 & 0.64 & 12.25 & \multirow{8}{*}{0.68} \\
\hline & PV3 & 0.61 & 11.33 & \\
\hline & PV4 & 0.76 & 15.13 & \\
\hline & PV5 & 0.69 & 13.22 & \\
\hline & PV6 & 0.66 & 12.64 & \\
\hline & PV7 & 0.62 & 11.47 & \\
\hline & PV8 & 0.69 & 13.22 & \\
\hline & PV9 & 0.72 & 14.00 & \\
\hline \multirow{4}{*}{ Trust } & $\mathrm{T} 1$ & 0.63 & 8.69 & \multirow{4}{*}{0.72} \\
\hline & $\mathrm{T} 2$ & 0.76 & 10.49 & \\
\hline & $\mathrm{T} 3$ & 0.76 & 10.49 & \\
\hline & $\mathrm{T} 4$ & 0.68 & 9.67 & \\
\hline \multirow{4}{*}{ Loyalty } & L1 & 0.79 & 15.12 & \multirow{4}{*}{0.83} \\
\hline & L2 & 0.86 & 16.83 & \\
\hline & L3 & 0.84 & 16.44 & \\
\hline & L4 & 0.81 & 15.51 & \\
\hline
\end{tabular}

\subsection{Structural Model and Test of Hypotheses}

A similar set of fit indices was used to examine the structural model. The results with their corresponding recommended values, provided evidence of a good model fit (x2/d.f. $=2.97$, $\mathrm{NFI}=0.92, \mathrm{GFI}=0.91, \mathrm{CFI}=0.91, \mathrm{RMSEA}=0.085)$. Regarding the hypothesis tests, perceived value hasa positive effect on trust $(\gamma 1=0.53$, $t$-value $=9.69)$. Thus, $\mathrm{H} 1$ was supported. Furthermore, perceived value was found to have a significant positive effect on passenger loyalty $(\gamma 2=0.53, \mathrm{t}$-value $=5.46)$, supporting hypothesis $\mathrm{H} 2$. The relationship coefficient between perceived value and trust was $0.78(\mathrm{PV} \rightarrow \mathrm{T})$, perceived value and passenger loyalty as 0.48 ( $\mathrm{PV} \rightarrow \mathrm{L}$ ) were found. So, it's been seen that a rise in perceived 
value per unit has a relatively high effect on trust with 0.78 increase rate, but medium-level effect (0.48) on passenger loyalty. The coefficients are positive and found statistically significant with $5 \%$ significance level. It can be stated that as the level of passengers' perceived value goes up, the level of passengers' trust and loyalty towards the airline company go up, too or vice versa.

Figure 2: Final Model

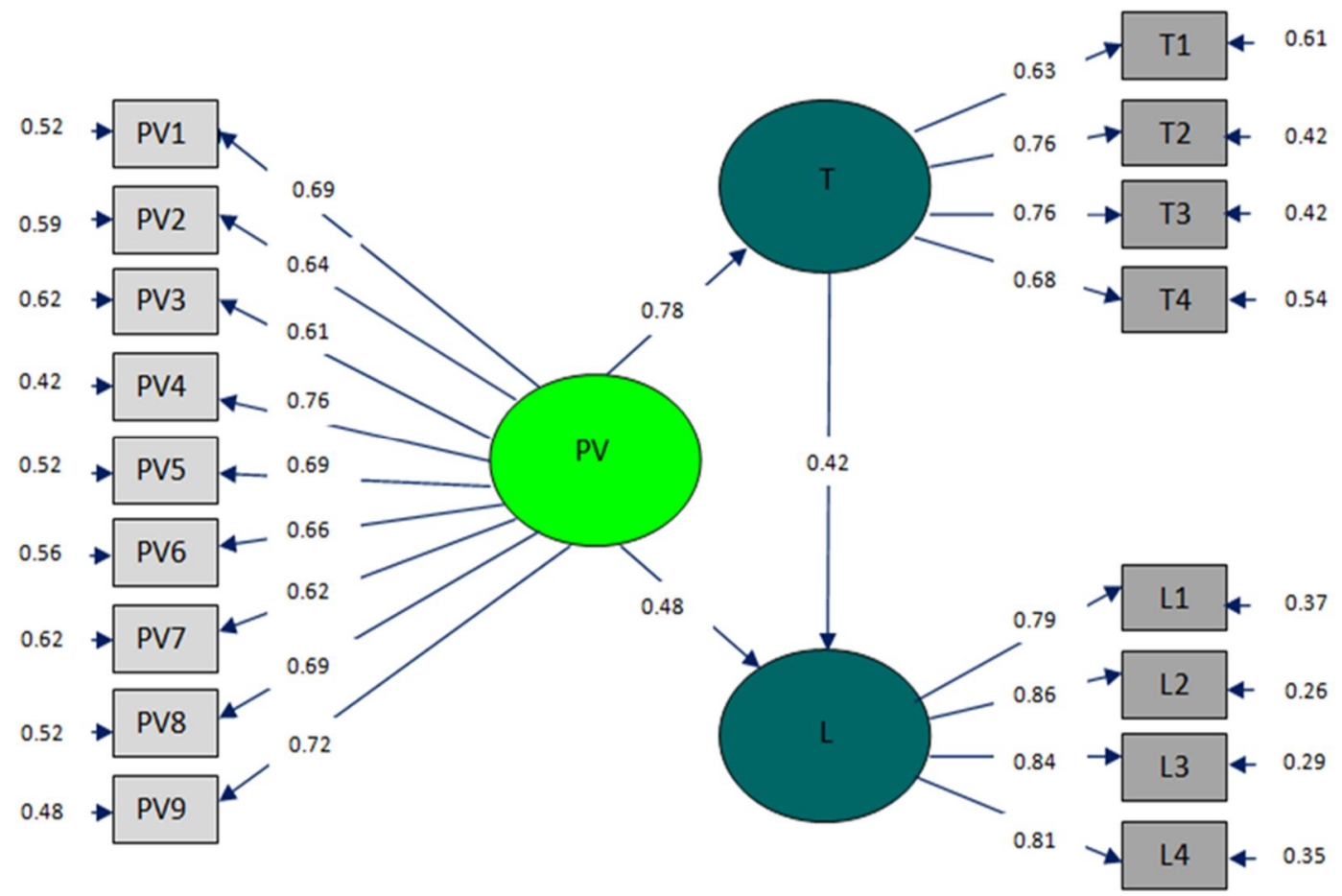

Finally, trust has been found as a significant determinant of passenger loyalty $(\gamma 3=1.02, t-$ value $=0.49)$, supporting $\mathrm{H} 3$. The relationship coefficient between trust and passenger loyalty was found as $0.42(T \rightarrow L)$. So, it's been seen that rise in trust per unit has less than a half effect on passenger loyalty.

\section{DISCUSSION AND CONCLUSION}

Having loyal customers is essential for the success of any company. In aviation industry too, loyalty of passengers especially for the LCC, serving basic service, that compete with traditional airlines, serving full service to their passengers, has become more important in today's competitive market. So, in this study, passenger loyalty has been studied and the results of this study have provided useful insights into the behaviours of LCC passengers.

Findings of this study revealed that LCC should have a positive social value and the personnel should be working professionally in order to increase the positive perceived value of the passengers. Social value includes the increase of airline image, having a better image than competitors and having preferred by many passengers. So, LCC should make an effort to differentiate themselves from their competitors. Furthermore, LCC should employ qualified 
personnel and they should train and motivate them in the best way. The personnel should have the necessary knowledge and abilities, brush up their job knowledge, be ready to help and behave politely to the passengers (Forgas, et al. 2010).

Besides, LCC should fulfil their responsibilities and concern passengers' needs properly. They have to offer their services right first time and with a continuous improvement to increase trust level of passengers. Also, LCC have to search and understand the needs and requests of passengers very well, listen to them, consider their complaints and customize their services according to the feedback they got from passengers (Forgas et al., 2010; Chang \& Hung, 2010).

In this study, perceived value was found as an important antecedent of trust (Forgas et al, 2010). So, in order to increase the trust level of passengers, LCC should have a good brand image than other airlines and the personnel should serve professionally to the whole passengers. Also, it's concluded that perceived value has a positive effect on passenger loyalty as consistent with other researhers' study (Forgas et al, 2010; Al-Refaie et al, 2013). Therefore, LCC should try to give better services by using online / mobile check-in, boarding systems and providing better baggage service. Furthermore, they should have modern, safe aircrafts, be on time, efficient flights with suitable times and frequencies. Besides, they should handle passengers' complaints and solve their problems immediately. All those services may be costly for LCC at first, but in the long run, it may pay for itself and also passenger loyalty of LCC and profits may be increased.

In addition, it's been found that there is a positive relationship between trust and loyalty similar to previous studies (Akamavi et al, 2015; Forgas et al, 2010; Han, 2013). Offering sincere and honest information to the passengers, fulfilling their commitments, meeting passengers' needs and having enough resources and experience to do their job well are very important for LCC to have a good trust level of passengers. Thus they may be able to maintain passenger loyalty. If passengers become loyal to the airline, they may repurchase the services of the same airline and provide positive word-of-mouth communication (Nadiri et al., 2008, Gures et al, 2014). Finally, price was found as the most important reason for selecting LCC as found in previous studies (Gures et al, 2014; Digginess, 2010; Mikulić \& Prebežac, 2011; O'connell \& Williams, 2005; Chiou \& Chen, 2010; Pan \& Truong, 2018). So LCC should give service at a cheaper price than competitors to attract more customers, provide and keep loyal passengers. 
Although this study contributes to airline marketing literature, it has several limitations too. In this study, the relationship among perceived value, trust and passenger loyalty were searched. As it is seen from this study, perceived value and trust have a relatively lower effect on passenger loyalty. So, some other variables should be included into the model to see their effects on passenger loyalty. Potential independent variables that can be studied in further studies are switching cost, customization, social media and some other variables.

Moreover, in this study only quantitative analysis was used. In the following studies, qualitative analysis should also be used to have better results. In addition, this study was applied to the passengers in two airports of Turkey. There are more airports in this country, so surveys should be applied in these airports too. Also in future studies, the number of passengers should be increased to reflect the population and get favourable results about passenger loyalty.

\section{REFERENCES}

- Akamavi, R.K., Mohamed, E., Pellmann, K. and Xu, Y., (2015), 'Key Determinants of Passenger Loyalty in the Low-cost Airline Business', Tourism Management, 46 (2015), 528545.

- Akbar, M. M. and Parvez, N. (2009), 'Impact of Service Quality, Trust, and Customer Satisfaction on Customers Loyalty', ABAC Journal, 29 (1), 24-38.

- Al-Refaie, A., Fouad, R.H. and Eteiwi, D. (2013), 'Examining Factors Affect Passenger's Satisfaction and Loyalty: A Comparative Analysis from Jordan Airport', Advances in information Sciences and Service Sciences (AISS), 5 (3), 641-650.

- Atalık, Ö. (2005), 'Havayolu İşletmeleri Örneğinde İşletme İmajının Havayolu İşletmesi Tercihlerine ve Müşteri Bağılığına Olan Etkisinin Belirlenmesine Yönelik Bir Araştırma', Türk Dünyası Dergisi, 7, 1-12.

- Atalık, Ö. (2006), 'The Impact of the Internet on Airline Customer Loyalty: Case of Turkish Air Travellers', South East European Journal of Economics and Business, Premier Issue, 64-78.

- Bachwich, A.R. and Wittman, M.D. (2017), 'The Emergence and Effects of the Ultra-Low Cost Carrier (ULCC) Business Model in the U.S. Airline Industry', Journal of Air Transport Management, 62, 155-164.

- Barrett, S. D. (2004), 'How Do the Demands for Airport Services Differ Between Full Service Carriers and Low-Cost Carriers?', Journal of Air Transport Management 10, 33-39.

- Bagozzi, R.P. and Yi, Y. (1988), 'On the Evaluation of Structural Equation Models', Journal of the Academy of Marketing Science, 16 (Spring), 74-94.

- Bhattacharya, R., Devinney, T. M. and Pillutla, M. M. (1998), A Formal Model of Trust Based on Outcomes', Academy of Management Review, 23(3), 459-472.

- Binggeli, U.,Gupta, S. and De Pommes, C. (2002), 'CRM in the Air', The McKinsey Quarterly, 3, 6-11.

- Calisir, N., Basak, E. and Calisir, F. (2016), 'Key Drivers of Passenger Loyalty: A Case of Frankfurt - Istanbul Flights', Journal of Air Transport Management, 53, 211-217.

- Caruana, A. (2004), 'The Impact of Switching Costs on Customer Loyalty: A Study Among Corporate Customers of Mobile Telephony', Journal of Targeting, Measurement and Analysis for Marketing, 12 (3), 256-268.

- Chang, L.Y. and Hung, S.C. (2013), 'Adoption and Loyalty toward Low Cost Carriers: The Case of Taipei-Singapore passengers', Transportation Research Part E, 50, 29-36. 
- Chen, C. F. (2008), Investigating Structural Relationships between Service Quality, Perceived Value, Satisfaction, and Behavioral Intentions for Air Passengers: Evidence from Taiwan, Transportation Research Part A: Policy and Practice, 42 (4), 709-717.

- Chiou, Y.C. and Chen, Y.H. (2010), 'Factors Influencing the Intentions of Passengers Regarding Full Service and Low Cost Carriers: A note', Journal of Air Transport Management, 16 (2010), 226-228.

- Cooil, B., Keiningham, T. L., Aksoy, L. and Hsu, M. (2007), 'A Longitudinal Analysis of Customer Satisfaction and Share of Wallet: Investigating the Moderating Effect of Customer Characteristics', Journal of Marketing, 71 (1), 67-83.

- Cronin, J. J., Brady, M. K. and Hult, G. T. M. (2000), 'Assessing the Effects of Quality, Value, and Customer Satisfaction on Consumer Behavioral Intentions in Service Environments', Journal of Retailing, 76 (2), 193-218.

- Diggines, C. (2010). Passenger Perceptions and Understanding of the Low-Cost and FullService Airline Models in South Africa and the Implications for Service Strategy. [Online] International Research Symposium in Service Management, Mauritius, 24-27.08.2010, Available at: http://web.uom.ac.mu/sites/irssm/papers/Diggines\%20 \%2012.pdf [Accessed: 01.03.2016].

- Forgas, S., Moliner, M.A., Sánchez, J. and Palau, R. (2010), 'Antecedents of Airline Passenger Loyalty: Low-cost versus Traditional Airlines', Journal of Air Transport Management, 16 (2010), 229-233.

- Fornell, C. and Larcker, D. F. (1981), 'Evaluating Structural Equation Models with Unobservable Variables and Measurement Error', Journal of Marketing Research, 18 (1), 39-50.

- Graf, L. (2005), 'Incompatibilities of The Low-cost and Network Carrier Business Models within The Same Airline Grouping', Journal of Air Transport Management, 11, 313-327.

- Griffin, J. (1995), Customer Loyalty: How to Earn It, How to Keep It. The Jossey-Bass Business Management Series. San Francisco: Jossey-Bass Publishers.

- Gundlach, G. T. and Murphy, P. E. (1993), 'Ethical and Legal Foundations of Relational Marketing Exchanges', The Journal of Marketing, 35-46.

- Gures, N., Arslan, S. and Yucel Tun, S. (2014), 'Customer Expectation, Satisfaction and Loyalty Relationship in Turkish Airline Industry', International Journal of Marketing Studies, $6(1), 66-74$.

- Hair, J.F., Black, W.C., Babin, B.J. and Anderson, R.E. (2010) Multivariate Data Analysis. Seventh Edition. Prentice Hall, Upper Saddle River, New Jersey.

- Han, H., Hyun, S.S. and Kim, W. (2014), 'In-flight Service Performance and Passenger Loyalty: A Cross-national (China / Korea) Study of Travelers Using Low-Cost Carriers', Journal of Travel \& Tourism Marketing, 31 (5), 589-609.

- Han, H. (2013), 'Effects of In-Flight Ambience and Space / Function on Air Travelers' Decision to Select A Low-Cost Airline', Tourism Management, 37 (2013), 125-135.

- IATA (2016) Passenger Facilitation, [Online] Available at: http://www.iata.org/whatwedo/passenger/Pages/passenger-facilitation.aspx [Accessed: 13.06.2018]

- Kangis, P. and O'Reilly, M. D. (2003), 'Strategies in A Dynamic Marketplace: A Case Study in The Airline Industry', Journal of Business Research, 56(2), 105-111.

- Kassim, N. and Asiah Abdullah, N. (2010), 'The Effect of Perceived Service Quality Dimensions on Customer Satisfaction, Trust, and Loyalty in E-Commerce Settings: A Cross Cultural Analysis', Asia Pacific Journal of Marketing and Logistics, 22(3), 351-371.

- Koklic, M.K., Kukar-Kinney, M. and Vegelj, S. (2017), 'An Investigation of Customer Satisfaction with Low-Cost and Full-Service Airline Companies', Journal of Business Research, 80, 188-196.

- Kumar, N. (2006), 'Strategies to Fight Low-Cost Rivals', Harvard Business Review, 84 (12), 104-112.

- Kumar, V. and Shah, D. (2004), Building and Sustaining Profitable Customer Loyalty for the 21st Century', Journal of Retailing, 80(4), 317-329.

- Lovelock, C. and Wirtz, J. (2011). Services marketing. 7/e, Pearson Education Limited, England. 
- Lu, J. L. (2017), 'Segmentation of Passengers Using Full-Service and Low-Cost Carriers Evidence From Taiwan', Journal of Air Transport Management, 62, 204-216.

- Mägi, A. W. (2003), 'Share of Wallet in Retailing: The Effects of Customer Satisfaction, Loyalty Cards and Shopper Characteristics', Journal of Retailing, 79(2), 97-106.

- McLay, P. and Reynolds-Feighan, A. (2006), 'Competition Between Airport Terminals: The Issues Facing Dublin Airport', Transportation Research Part A, 40, 181 - 203.

- Mikulić, J. and Prebežac, D. (2011), 'What Drives Passenger Loyalty to Traditional and LowCost Airlines? A Formative Partial Least Squares Approach', Journal of Air Transport Management, 17 (2011), 237- 240.

- Mutlu, H.M. and Polat Sesliokuyucu, İ. (2015), 'The Relationship Between Ground Service Quality and Customer Loyalty', International Academic Conference on Management, Economics and Marketing, Hungary, Budapest (IAC-MEM 2015), 217-223.

- Nadiri, H., Hussain, K., Ekiz, E.H. and Erdoğan, Ş. (2008), 'An Investigation on the Factors Influencing Passengers' Loyalty in the North Cyprus National Airline', The TQM Journal, 20(3), 265-280.

- O'Connell, J.F. and Williams, G. (2005), 'Passengers' Perceptions of Low Cost Airlines and Full Service Carriers: A Case Study Involving Ryanair, Aer Lingus, Air Asia and Malaysia Airlines', Journal of Air Transport Management, 11 (2005), 259-272

- Oh, H. (1999), 'Service Quality, Customer Satisfaction, and Customer Value: A Holistic Perspective', International Journal of Hospitality Management, 18(1), 67-82.

- Oliver, R.L. (1999), 'Whence Consumer Loyalty?', Journal of Marketing, 63, Fundamental Issues and Directions for Marketing, 33-44.

- Ndubisi, O. N. (2007), 'Relationship Marketing and Customer Loyalty', Marketing Intelligence \& Planning, 25(1), 98-106.

- Pan, J.Y., and Truong, D. (2018), 'Passengers' Intentions to Use Low-Cost Carriers: An Extended Theory of Planned Behavior Model', Journal of Air Transport Management, 69, 38-48.

- Porter, M. E. (1996), 'What is the strategy?', Harvard Business Review, 74 (6), 61-78.

- Rajaguru, R. (2016), 'Role of Value for Money and Service Quality on Behavioural Intention: A Study of Full Service and Low Cost Airlines', Journal of Air Transport Management, 53, 114-122.

- Reichheld, F. F. and Sasser,W. E., Jr. (1990), 'Zero Defections: Quality Comes to Services', Harvard Business Review, 68(5), 105-111.

- Reichheld, F. F. and Schefter, P. (2000), 'E-loyalty', Harvard business review, 78(4), 105113.

- Sánchez-Fernández, R. and Iniesta-Bonillo, M. Á. (2007), 'The Concept of Perceived Value: A Systematic Review of The Research', Marketing Theory, 7(4), 427-451.

- Severt, D., Wang, Y., Chen, P.J. and Breiter, D. (2007), 'Examining the Motivation, Perceived Performance, and Behavioural Intentions of Convention Attendees: Evidence from A Regional Conference, Tourism Management, 28, 399-408.

- Sirdeshmukh, D., Singh, J. and Sabol, B. (2002), Consumer Trust, Value, and Loyalty in Relational Exchanges', Journal of Marketing, 66(1), 15-37.

- Snoj, B., Korda, A. P. and Mumel, D. (2004), 'The Relationships Among Perceived Quality, Perceived Risk and Perceived Product Value', Journal of Product \& Brand Management, 13(3), 156-167.

- Taumoepeau, S., Towner, N. and Losekoot, E. (2017), 'Low-Cost Carriers in Oceania, Pacific: Challenges and Opportunities', Journal of Air Transport Management, 65, 40-42.

- Urban, G. L., Sultan, F. and Qualls, W. J. (2000), 'Placing Trust at the Center of Your Internet Strategy', MIT Sloan Management Review, 42(1), 39.

- Wirtz, J., Mattila, A. S. and Lwin, M. O. (2007), 'How Effective Are Loyalty Reward Programs in Driving Share of Wallet?', Journal of Service Research, 9(4), 327-334.

- Yang, K.C., Hsieh, T.C., Li, H. and Yang, C. (2012), 'Assessing How Service Quality, Airline Image and Customer Value Affect The Intentions of Passengers Regarding Low Cost Carriers', Journal of Air Transport Management, 20 (2012), 52-53.

- Yang, J.Y. and Liu, A. (2003), 'Frequent Flyer Program: A Case Study of China Airline's Marketing Initiative - Dynasty Flyer Program', Tourism Management, 24(5), 587-595. 
- Yang, Z. and Peterson, R. T. (2004), 'Customer Perceived Value, Satisfaction, and Loyalty: The Role of Switching Costs', Psychology \& Marketing, 21(10), 799-822.

- Zeithaml, V.A. (1988), 'Consumer Perceptions of Price, Quality and Value: A Means-End model and Synthesis of Evidence', Journal of Marketing, 52, 2-22.

- Zou, B., Elke, M., Hansen, M. and Kafle, N. (2014), 'Evaluating Air Carrier Fuel Efficiency in the US Airline Industry', Transportation Research Part A: Policy and Practice, 59, 306330.

- Zuidberg, J. and de Wit, J. (2016), 'What Makes the Difference Between A Low-Cost Carrier Airport and A Low-Cost Carrier Base?', Research in Transportation Business \& Management, 21, 11-18.

\section{APPENDIX}

Trust

T1 The information offered by the company is sincere and honest

T2 In general the company fulfils its commitments

T3 The company is concerned for its customers' needs

T4 The company has the resources and experience to do its job well

\section{Perceived Value}

PV1 Airport installations seem well organized

PV2 The aircraft seem modern, comfortable and safe

PV3 The personnel know their job well

PV4 This company's planes arrive and leave punctually

PV5 The service is good for the price paid

PV6 The queues to check-in are reasonable

PV7 It is no problem that the airport is far from the city of origin/destination

PV8 I feel happy with the service

PV9 This company has a very good image

\section{Passenger Loyalty}

L1 I like flying with this company

L2 I believe it is a good company

L3 I will continue to travel with this company

L4 I will continue to recommend this company 